\title{
TATA RUANG DALAM RUMAH SEDERHANA T-54 PERUMAHAN KEDUNG BADAK BARU BOGOR DITINJAU DARI PENCAHAYAAN
}

\author{
Mochammad Ardi Prayoga ${ }^{1}$, Hartanto Budiyuwono ${ }^{2}$, Rahadian Prajudi ${ }^{3}$ \\ Magister Arsitektur, Program Pascasarjana, Universitas Katolik Parahyangan, Bandung \\ Jl. Merdeka, No. 30, Bandung - Indonesia \\ Email: mardiprayoga@yahoo.com ${ }^{1}$, hh26118@gmail.com², candinusantara@gmail.com ${ }^{3}$
}

\begin{abstract}
Abstrak
Populasi masyarakat Indonesia menuntut akan rumah tinggal seperti halnya pada rumah dengan tipe luas bangunan $54 \mathrm{~m}^{2}$. Penempatan bangunan tersebut beragam tata letaknya terhadap orientasi matahari yang terpengaruh pula terhadap pencahayaan. Hal ini memunculkan fenomena program pembangunan rumah sederhana. Isu dari penelitian ini adalah tata ruang dalam rumah sederhana tipe 54 yang ditinjau dari pencahayaan. Fokus penelitian ini adalah bangunan rumah tinggal sederhana tipe 54 di Komplek Perumahan Kedung Badak Baru Kota Bogor. Tujuan penelitian ini untuk mendapatkan pedoman perancangan tata ruang dalam bangunan rumah tinggal sederhana tipe 54 yang mempertimbangkan pencahayaan dan diharapkan dapat memberi masukan bagi perencana dan pemerintah di Kota Bogor. Metode yang digunakan adalah metode penelitian kuantitatif deskriptif analitik. Teori perancangan arsitektur tropis dan teori pencahayaan digunakan sebagai acuan dasar dalam membuat analisis. Hasil dari penelitian ini adalah ruang dalam yang gelap karena adanya ruangan yang terkurung dan penempatan tipe bukaan yang tidak tepat. Simpulan yang didapat adalah perubahan tata ruang dalam berdasarkan orientasi bangunan dan tipe bukaan yang ditempatkan secara tepat akan dapat memanfaatkan cahaya.
\end{abstract}

Kata kunci: rumah sederhana tipe 54, tata ruang dalam, pencahayaan

\begin{abstract}
Title: Layout of Type 54 Affordable House in Kedung Badak Bogor City based on Lighting

Indonesian people considered the house as a basic necessity such as a house with a building area of $54 \mathrm{~m}^{2}$. The placement of the various layout to the sun's orientation is related to the lightning. This lead to the phenomenon of affordable housing development. The issue of this research is the layout of type 54 affordable house considered by the lighting. The focus of this research is the type 54 affordable house in Kedung Badak Baru in Bogor. The purpose of this research is to get layout design guidelines of type 54 affordable house which consider the lighting and give input to the next architect and government in Bogor. The research method is quantitative descriptive analytic. Tropical architecture design theory and lighting theory are used as a reference in making an analysis. The result is the interior less bright. It because the layout design was surrounded by another room and incorrect placement and size of openings. The conclusion is to design new layout based each orientation of type 54 affordable house. And it also to place the suitable openings properly which will able to utilize the light.
\end{abstract}

Keywords: affordable house type 54, layout, lighting 


\section{Pendahuluan}

Dalam tiga dekade pertama paska kemerdekaan, pemerintah Indonesia mencanangkan program-program pembangunan. Masyarakat Indonesia melihat rumah tinggal sebagai kebutuhan dasar dan populasi masyarakat Indonesia yang tinggi menimbulkan tingginya permintaan hunian. Siswono Yudohusodo (1994) menyebutkan bahwa rumah yang layak berarti tidak hanya sekedar atap berlindung seseorang, akan tetapi juga agar dapat dinikmati kebebasan pribadi, luas lantai yang cukup, lokasi yang dekat dengan tempat kerja dan fasilitas umum lainnya yang memadai. Kesemuanya itu agar diusahakan dapat diperoleh pada tingkat harga yang terjangkau oleh masyarakat banyak. Hal ini memunculkan fenomena program pembangunan rumah sederhana. Upaya yang dilakukan diantaranya dengan menyeragamkan aspek bentuk, dimensi ruang, dan material pada rumah-rumah sederhana.

Isu dari penelitian ini adalah aspek pencahayaan dari rumah sederhana tipe 54 yang tidak dapat dimanfaatkan dengan baik karena bentuk tata ruang dalam rumah sederhana tipe 54 yang beragam. Hal ini menyebabkan ruang dalam rumah sederhana tipe 54 menjadi gelap. Oleh karena itu perlu diadakan suatu penelitian terhadap tata ruang dalam bangunan rumah tingal sederhana yang ditinjau dari pencahayaan pada bangunan rumah tinggal sederhana guna mendapatkan acuan desain bangunan rumah tinggal sederhana tipe 54 yang memiliki tata ruang dalam yang baik dengan mempertimbangkan aspek pencahayaan.

\section{Metode Penelitian}

Penelitian berdasarkan metode penelitian kuantitatif deskriptif analitik yakni metode dengan mengumpulkan data yang diambil dari hasil pengamatan, wawancara, dokumentasi, catatan lapangan, pengukuran dengan lux meter, literatur, aplikasi ecotect dan sketch up, dan analisa. Hasil pengolahan tersebut berupa pemaparan yang disajikan dalam bentuk narasi.

\section{Lingkup Penelitian}

Fokus penelitian ini adalah bangunan rumah tinggal sederhana tipe 54 di Komplek Perumahan Kedung Badak Baru Kota Bogor. Rumah sederhana yang terbangun di Perumahan Kedung Badak Baru adalah tipe 45, tipe 54, dan tipe 70. Tipe-tipe rumah tersebut sebagai bentuk penyikapan pengembang terhadap kebutuhan rumah tinggal yang cepat dan terjangkau untuk dibangun. Rumah sederhana tipe 54 ini dibangun secara seragam, keseragaman itulah yang membuat cahaya alami tidak dapat dimanfaatkan dengan baik sehingga ruang-ruang dalam kekurangan pencahayaan.

Langkah-langkah penelitian:

1. Pemilihan objek studi yaitu rumah tinggal sederhana tipe 54 Perumahan Kedung Badak Baru Kota Bogor;

2. Identifikasi dan perumusan masalah tata ruang dalam rumah tinggal sederhana tipe 54 Perumahan Kedung Badak Baru Kota Bogor ditinjau dari aspek pencahayaan;

3. Mendefinisikan pengertian serta pemahaman mengenai tata ruang dalam bangunan rumah tinggal sederhana tipe 54 Perumahan 
Kedung Badak Baru Kota Bogor yang ditinjau dari aspek pencahayaan yang berkenaan dalam penelitian melalui telaah kajian teoritis berdasarkan studi literatur, dari buku, jurnal, maupun artikel, dan studi preseden;

4. Melakukan kegiatan obsevasi langsung ke lapangan dan melakukan kegiatan dokumentasi dan pengukuran cahaya dengan lux meter terhadap bangunan rumah tinggal sederhana tipe 54 Perumahan Kedung Badak Baru Kota Bogor;

5. Analisis dan sintesis data lapangan. Setelah observasi lapangan, datadata rumah tinggal sederhana tipe 54 Perumahan Kedung Badak Baru Kota Bogor dihimpun dan dengan aplikasi sketch up dan ecotect digunakan simulasi. Kemudian datadata tersebut diolah dan dianalisis untuk menghasilkan solusi desain;

6. Simpulan hasil penelitian. Dilakukan sebagai jawaban atas pernyataan penelitian yang kemudian diaplikasikan pada contoh desain rumah sederhana tipe 54 Perumahan Kedung Badak Baru Kota Bogor.

\section{Objek Studi}

Objek studi adalah rumah tinggal sederhana tipe 54 yang berada di Perumahan Kedung Badak Kota Bogor. Kota Bogor sendiri terletak diantara $106^{0} 43^{\prime} 30^{\prime \prime}$ BT - $106^{0} 51^{\prime} 00^{\prime \prime}$ BT dan 30'30" LS - 6041'00" LS. Ketinggian antara $190 \mathrm{~m} \mathrm{~s} / \mathrm{d} 330 \mathrm{~m}$ dpl. Suhu udara rata-rata $26^{\circ} \mathrm{C}$ dan kelembapan $70 \%$. Terletak pada kaki Gunung Salak dan Gunung Gede sehingga kaya akan hujan orografi.

\section{Tabel 1. Data umum objek studi}

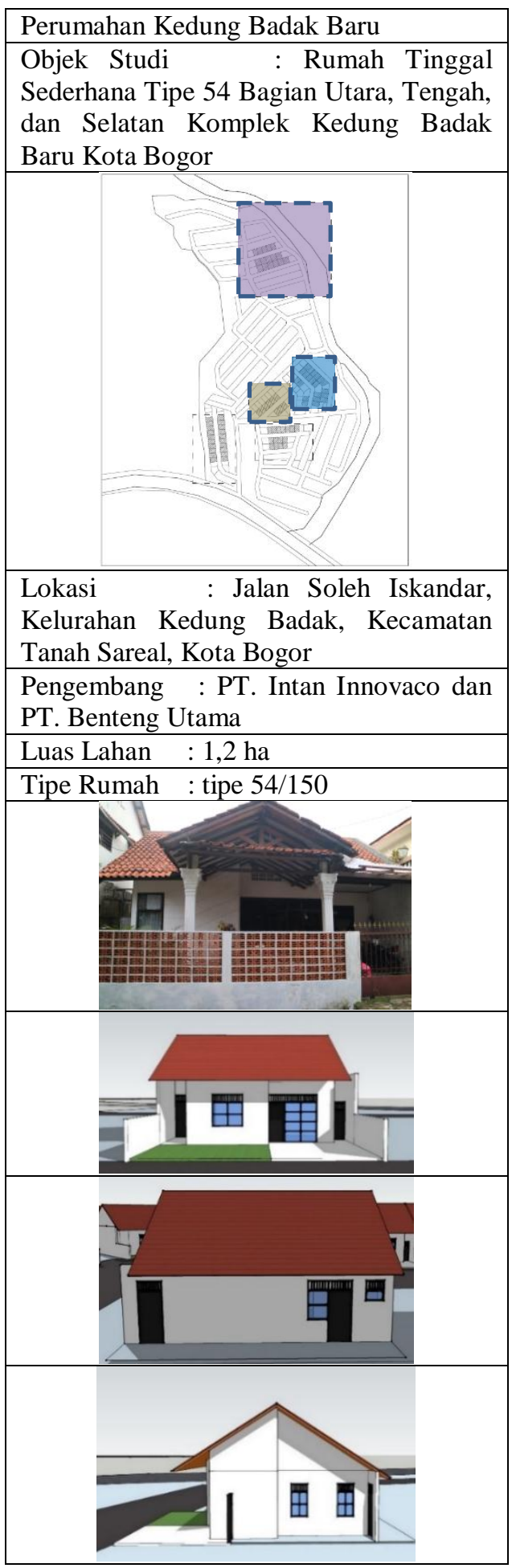




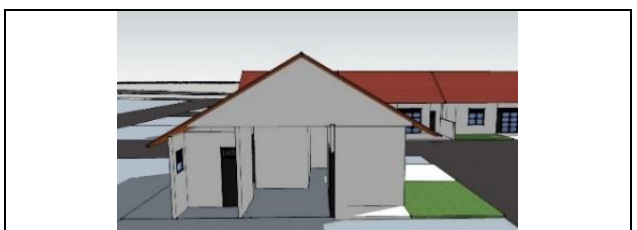

Sumber: Dokumentasi penulis dan hasil simulasi, 2017

\section{Pembahasan Analisis Rumah Tinggal Sederhana Tipe 54}

\section{Tabel 2. Analisis rumah tipe 54}

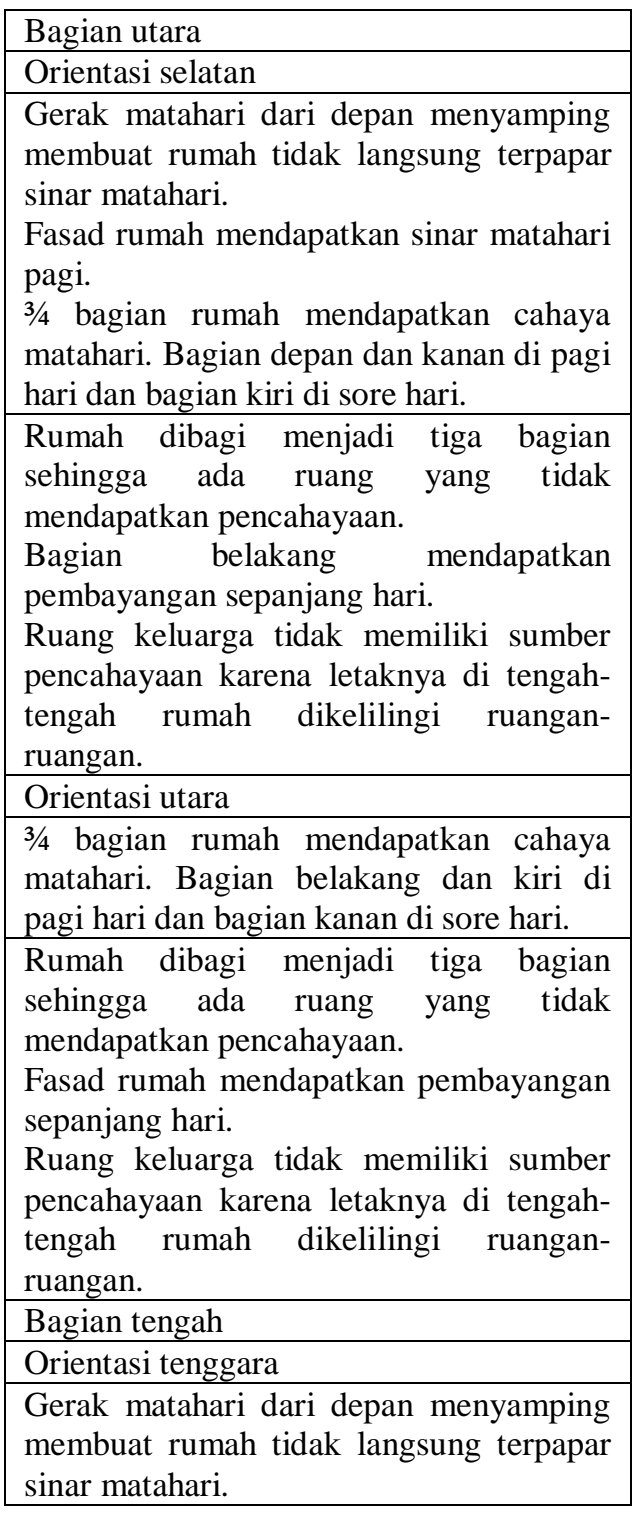

Fasad rumah mendapatkan sinar matahari pagi.

$3 / 4$ bagian rumah mendapatkan cahaya matahari. Bagian depan dan kanan di pagi hari dan bagian kiri di sore hari.

Rumah dibagi menjadi tiga bagian sehingga ada ruang yang tidak mendapatkan pencahayaan.

Bagian belakang mendapatkan pembayangan sepanjang hari.

Ruang keluarga tidak memiliki sumber pencahayaan karena letaknya di tengahtengah rumah dikelilingi ruanganruangan.

Orientasi barat laut

Gerak matahari dari depan menyamping membuat rumah tidak langsung terpapar sinar matahari.

$3 / 4$ bagian rumah mendapatkan cahaya matahari. Bagian belakang dan kiri di pagi hari dan bagian kanan di sore hari.

Fasad rumah mendapatkan pembayangan sepanjang hari.

Rumah dibagi menjadi tiga bagian sehingga ada ruang yang tidak mendapatkan pencahayaan.

Ruang keluarga tidak memiliki sumber pencahayaan karena letaknya di tengahtengah rumah dikelilingi ruanganruangan.

Bagian timur

Orientasi barat daya

Gerak matahari dari samping membuat rumah tidak langsung terpapar sinar matahari.

3/4 bagian rumah mendapatkan cahaya matahari. Bagian belakang dan kanan di pagi hari dan bagian depan di sore hari.

Rumah dibagi menjadi tiga bagian sehingga ada ruang yang tidak mendapatkan pencahayaan.

Fasad rumah tidak mendapatkan sinar matahari pagi.

Bagian kiri rumah mendapatkan pembayangan sepanjang hari.

Ruang keluarga tidak memiliki sumber pencahayaan karena letaknya di tengahtengah rumah dikelilingi ruanganruangan.

Orientasi timur laut

Gerak matahari dari samping membuat rumah tidak langsung terpapar sinar matahari. 


\begin{tabular}{l} 
Fasad rumah mendapatkan sinar matahari \\
pagi. \\
$3 / 4$ bagian rumah mendapatkan cahaya \\
matahari. Bagian depan dan kiri di pagi \\
hari dan bagian belakang di sore hari. \\
\hline Rumah dibagi menjadi tiga bagian \\
sehingga ada ruang yang tidak \\
mendapatkan pencahayaan. \\
Bagian kanan mendapatkan pembayangan \\
sepanjang hari. \\
Ruang keluarga tidak memiliki sumber \\
pencahayaan karena letaknya di tengah- \\
tengah rumah dikelilingi ruangan- \\
ruangan.
\end{tabular}

Sumber: Hasil analisis, 2017

\section{Konsep Desain Rumah Tinggal Sederhana Tipe 54}

Secara khusus, Habraken (1976) menunjukan beberapa faktor yang menyebabkan manusia merubah huniannya, yaitu :

1. Kebutuhan akan pengenalan diri (identification). Kebutuhan ini dianggap sebagai kebutuhan dasar fungsional dimana standar dijadikan alat umum.

2. Perubahan gaya hidup (life style). Perubahan ini disebabkan karena adanya perpaduan dengan budaya lain dan munculnya pandanganpandangan.

3. Kemungkinan-kemungkinan baru akibat teknologi. Keinginan untuk mengikuti perkembangan zaman.

4. Perubahan struktur keluarga

Berdasarkan hasil analisis mengenai tata ruang dalam rumah tinggal sederhana tipe 54 yang ditinjau dari aspek pencahayaan dan dari teori yang sudah diterapkan muncul pedoman tata ruang dalam yang baik yang mempertimbangkan pencahayaan yang baik pula.
Tabel 3. Pedoman desain

\begin{tabular}{|c|c|}
\hline & Pedoman desain \\
\hline & Rumah hanya terdiri dari 1 lantai \\
\hline & Luas bangunan $\leq 54 \mathrm{~m}^{2}$. \\
\hline & Lima bagian pokok rumah : \\
\hline & 1. Atap \\
\hline & 2. Pendukung atap \\
\hline & 3. Alas atau sendi \\
\hline & 4. Lantai \\
\hline & 5. Dinding \\
\hline & $\begin{array}{l}\text { Membagi dua rumah menjadi dua bagian } \\
\text { (depan dan belakang). }\end{array}$ \\
\hline & $\begin{array}{l}\text { Mendekatkan ruang tamu dengan ruang } \\
\text { keluarga dan ruang makan agar ruangan } \\
\text { terasa lebih besar. Meletakan area servis } \\
\text { seperti ruang cuci dan ruang jemur di luar } \\
\text { rumah. }\end{array}$ \\
\hline & Di dalam rumah terdapat : \\
\hline & 1. Ruang tamu $\left(\geq 9 \mathrm{~m}^{2}\right)$ \\
\hline & 2. Ruang makan $\left(\geq 6 \mathrm{~m}^{2}\right)$ \\
\hline & 3. Ruang keluarga $\left(\geq 9 \mathrm{~m}^{2}\right)$ \\
\hline & 4. Kamar tidur utama $\left(\geq 9 \mathrm{~m}^{2}\right)$ \\
\hline & 5. Kamar tidur anak $\left(\geq 6 \mathrm{~m}^{2}\right)$ \\
\hline & 6. $\quad$ Kamar mandi $\left(\geq 2 \mathrm{~m}^{2}\right)$ \\
\hline & 7. Dapur $\left(\geq 4 \mathrm{~m}^{2}\right)$ \\
\hline & Pencahayaan \\
\hline & $\begin{array}{l}\text { Bukaan ditempatkan pada daerah yang } \\
\text { terkena sinar matahari langsung. }\end{array}$ \\
\hline & $\begin{array}{lcr}\text { Bidang-bidang } & \text { masif ditempatkan di } \\
\text { daerah-daerah } & \text { yang } & \text { mendapat } \\
\text { pencahayaan. } & & \\
\end{array}$ \\
\hline & $\begin{array}{l}\text { Meminimalisir daerah-daerah yang } \\
\text { mendapat pembayangan. }\end{array}$ \\
\hline
\end{tabular}

Sumber: Hasil analisis, 2017

Konsep Perancangan Rumah Tinggal Sederhana Tipe 54

Mangunwijaya (1980) menyebutkan bahwa ada lima bagian pokok rumah yang merupakan sarana dasar setiap rumah, antara lain :

1. Atap

2. Pendukung Atap

3. Alas atau Sendi

4. Lantai

5. Dinding

Konsep Penataan Rumah Tinggal Sederhana Tipe 54 
Suryowiyono (1982) mengatakan bahwa pada dasarnya suatu rumah tinggal merupakan kesatuan yang teradu dari berbagai ruang dengan fungsi dan sifat yang berbeda-beda.

\section{Tabel 4. Pedoman penataan ruang dalam}

Konsep penataan rumah dibagi menjadi dua bagian, depan belakang atau kiri dan kanan. Hal ini bertujuan untuk memisahkan zona publik dan zona privat. Ruang tamu, ruang keluarga, ruang makan, dan dapur termasuk ke dalam zona publik. Sedangkan kamar tidur utama, kamar tidur anak, dan kamar mandi termasuk pada ruang privat.

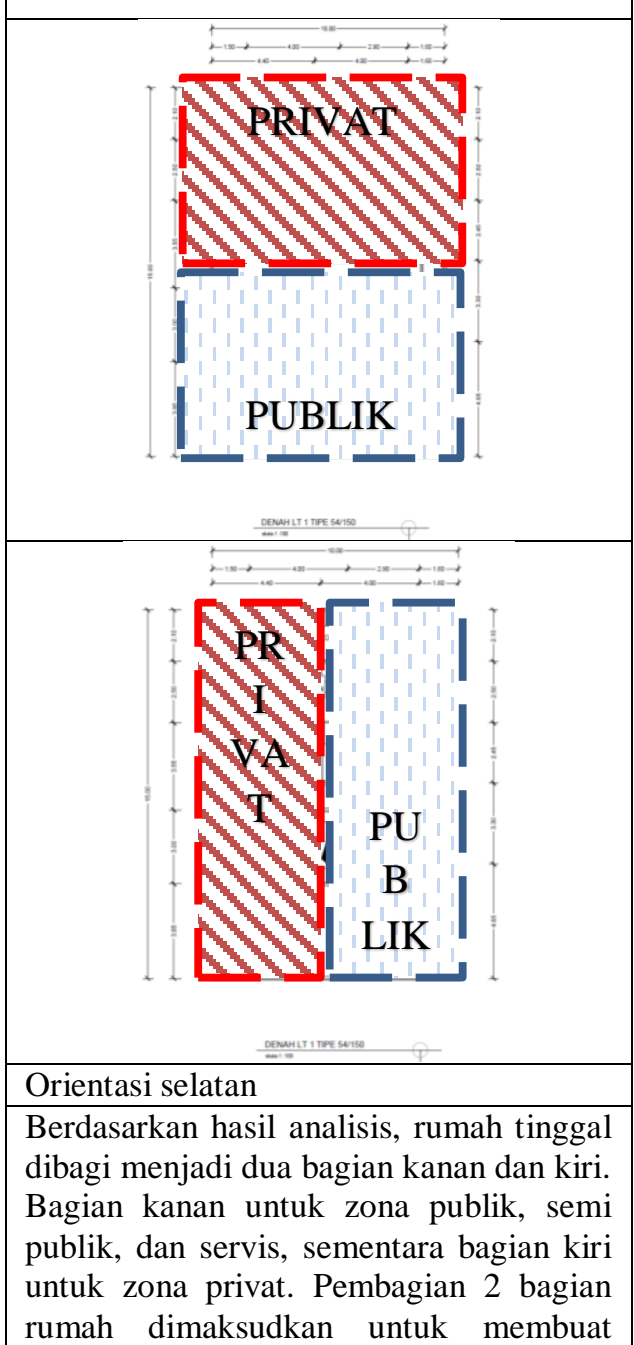

penghuni lebih leluasa dan nyaman dalam menjalankan aktivitas. Selain itu pembagian tersebut dimaksudkan untuk membuat ruang mendapatkan pencahayaan.

\section{Orientasi utara}

Penyebab gelapnya ruang dalam adalah adanya ruangan yang dikelilingi ruang lain sehingga tidak memiliki pencahayaan. Oleh karena itu rumah dibagi dua bagian, depan dan belakang. Bagian depan untuk zona publik, semi publik, dan servis, sementara bagian belakang untuk zona privat. Pembagian 2 bagian rumah dimaksudkan untuk membuat penghuni lebih leluasa dan nyaman dalam menjalankan aktivitas.

\section{Orientasi tenggara}

Penyebab gelapnya ruang dalam adalah adanya ruangan yang dikelilingi ruang lain sehingga tidak memiliki pencahayaan. Oleh karena itu rumah dibagi dua bagian, depan dan belakang. Bagian depan untuk zona publik, semi publik, dan servis, sementara bagian belakang untuk zona privat. Pembagian 2 bagian rumah dimaksudkan untuk membuat penghuni lebih leluasa dan nyaman dalam menjalankan aktivitas.

Orientasi barat laut

Penyebab gelapnya ruang dalam adalah adanya ruangan yang dikelilingi ruang lain sehingga tidak memiliki pencahayaan. Oleh karena itu rumah dibagi dua bagian, depan dan belakang. Bagian depan untuk zona publik, semi publik, dan servis, sementara bagian belakang untuk zona privat. Pembagian 2 bagian rumah dimaksudkan untuk membuat penghuni lebih leluasa dan nyaman dalam menjalankan aktivitas selain itu pembagian tersebut dimaksudkan untuk membuat ruang mendapatkan pencahayaan dari matahari yang bergerak dari belakang secara diagonal ke kanan. Pembagian zona publik di depan dimaksudkan untuk memanfaatkan cahaya matahari sore dan zona privat di belakang untuk memanfaatkan cahaya matahari pagi.

Orientasi barat daya

Penyebab gelapnya ruang dalam adalah adanya ruangan yang dikelilingi ruang 


\begin{tabular}{l} 
lain sehingga tidak memiliki \\
pencahayaan. Oleh karena itu rumah \\
dibagi dua bagian, depan dan belakang. \\
Bagian depan untuk zona public, semi \\
publik, dan servis, sementara bagian \\
belakang untuk zona privat. Pembagian 2 \\
bagian rumah dimaksudkan untuk \\
membuat penghuni lebih leluasa dan \\
nyaman dalam menjalankan aktivitas \\
selain itu pembagian tersebut \\
dimaksudkan untuk membuat ruang \\
mendapatkan pencahayaan dari matahari \\
yang bergerak dari kanan. Pembagian \\
zona publik di depan dimaksudkan untuk \\
memanfaatkan cahaya matahari sore dan \\
zona privat di belakang untuk \\
memanfaatkan cahaya matahari pagi. \\
Orientasi timur laut \\
\hline Penyebab gelapnya ruang dalam adalah \\
adanya ruangan yang dikelilingi ruang \\
lain sehingga tidak memiliki \\
pencahayaan. Oleh karena itu rumah \\
dibagi dua bagian, depan dan belakang. \\
Bagian depan untuk zona publik, semi \\
publik, dan servis, sementara bagian \\
belakang untuk zona privat. Pembagian 2 \\
bagian rumah dimaksudkan untuk \\
membuat penghuni lebih leluasa dan \\
nyaman dalam menjalankan aktivitas \\
selain itu pembagian tersebut \\
dimaksudkan untuk membuat ruang \\
mendapatkan pencahayaan dari matahari \\
yang bergerak dari kanan. Pembagian \\
zona publik di depan dimaksudkan untuk \\
memanfaatkan cahaya matahari sore dan \\
zona privat di belakang untuk \\
memanfaatkan cahaya matahari pagi. \\
\hline
\end{tabular}

Sumber: Hasil analisis, 2017

\section{Konsep Bukaan Rumah Tinggal Sederhana Tipe 54}

Karyono (2016) menyebutkan orientasi atau hadapan bangunan mempengaruhi tinggi rendahnya temperatur udara di dalam ruang. Di kawasan sekitar khatulistiwa, sisi barat-timur mendapatkan kalor yang lebih banyak dibanding sisi utara-selatan.

\section{Tabel 5. Konsep bukaan}

Berdasarkan hasil analisis data lapangan dan juga aplikasi sketch up dan ecotect didapatkan tipe bukaan dengan bentuk yang berbeda-beda di tiap sisinya. Hal tersebut dimaksudkan untuk mendapatkan pencahayaan dari sinar matahari. Bukaan dapat berupa jendela maupun kaca mati. Kusen bukaan dapat berupa kayu maupun alumunium. Lebar kusen sebesar $5 \mathrm{~cm}$.

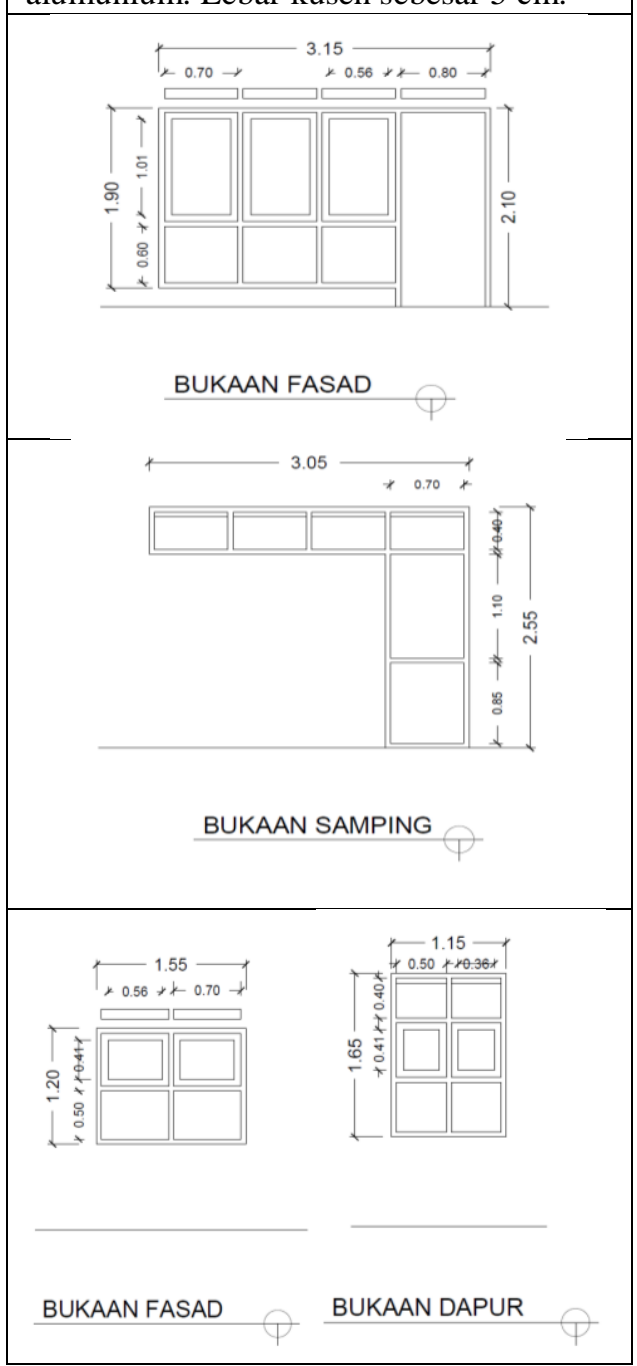




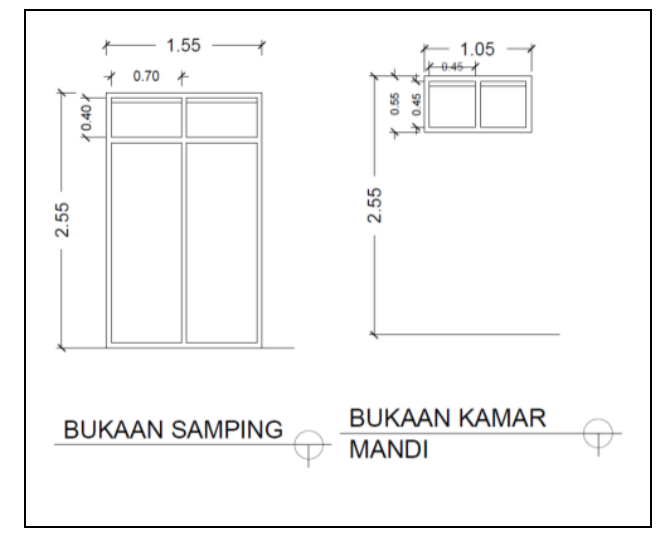

Sumber: Hasil analisis, 2017

Tabel 6. Penerapan konsep bukaan pada rumah tinggal sederhana tipe 54

\begin{tabular}{l} 
Rumah sederhana tipe 54 orientasi selatan \\
Dimensi \\
\hline \begin{tabular}{l} 
Dimensi rumah mengalami perubahan, \\
lebarnya berubah menjadi 6 meter, dan \\
panjangnya berubah menjadi 8 meter. Hal \\
ini dimaksudkan untuk memberi jarak \\
dinding rumah dengan dinding tetangga \\
dan agar bangunan dapat memanfaatkan \\
pergerakan matahari di perumahan bagian \\
utara. \\
\hline Pembagian ruang \\
Ruang dalam dibagi menjadi dua bagian, \\
zona public berada di kanan sementara \\
zona privat di kiri. Di bagian kiri terdapat \\
kamar tidur utama, 2 kamar tidur anak, \\
dan kamar mandi dan dimaksudkan agar \\
ruang-ruang tersebut mendapakan sinar \\
matahari sore. Sementara di bagian kanan \\
terdapat ruang tamu, ruang keluarga, \\
ruang makan, dan dapur dan \\
dimaksudkan untuk dapat memanfaatkan \\
sinar matahari pagi. \\
Bukaan \\
Dengan orientasi menghadap ke selatan, \\
bukaan \\
bangunan. Hal ini agar fasad bangunan
\end{tabular} \\
\hline
\end{tabular}

dan tampak kanan bangunan dapat memanfaatkan sinar matahari pagi dan tampak kiri dan belakang dapat memanfaatkan sinar matahari sore. Fasad depan rumah ini ditempatkan pintu yang disatukan dengan jendela pada ruang tamu, dan jendela pada kamar tidur utama. Tampak kanan bangunan ditempatkan kaca pada ruang tamu dan jendela dan bouvenlicht. Pada tampak kiri ditempatkan kaca mati pada kamar tidur utama dan jendela pada tiap kamar tidur anak. Dan tampak belakang ditempatkan jendela pada dapur.

\section{Rumah sederhana tipe 54 orientasi utara}

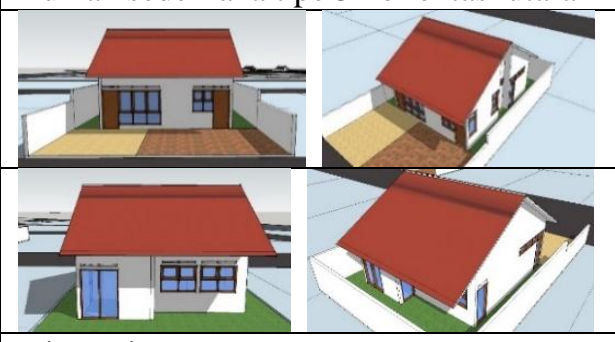

Dimensi

Dimensi rumah mengalami perubahan, lebarnya berubah menjadi 7 meter, dan panjangnya berubah menjadi 8 meter. Hal ini dimaksudkan untuk memberi jarak dinding rumah dengan dinding tetangga dan agar bangunan dapat memanfaatkan pergerakan matahari di perumahan bagian utara.

Pembagian ruang

Ruang dalam dibagi menjadi dua bagian, zona public berada di depan sementara zona privat di belakang. Di bagian belakang terdapat kamar tidur utama dan 2 kamar tidur anak, dimaksudkan agar ruang-ruang tersebut mendapakan sinar matahari pagi. Sementara di bagian depan terdapat ruang tamu, ruang keluarga, ruang makan, dapur, dan kamar mandi dimaksudkan untuk dapat memanfaatkan sinar matahari pagi.

\begin{tabular}{l}
\hline Bukaan \\
Dengan orientasi menghadap ke utara, \\
bukaan ditempatkan disekeliling \\
bangunan. Hal ini agar fasad bangunan \\
dan tampak kanan bangunan dapat \\
memanfaatkan sinar matahari sore dan \\
tampak kiri dan belakang dapat \\
memanfaatkan sinar matahari pagi. Fasad \\
depan rumah ini ditempatkan pintu yang
\end{tabular}


disatukan dengan jendela pada ruang tamu dan ruang makan. Tampak kanan bangunan ditempatkan bouvenlicht pada kamar mandi kaca mati pada ruang makan, dan jendela pada dapur dan kamar tidur utama. Pada tampak kiri ditempatkan kaca mati pada kamar tidur anak dan ruang tamu. Dan tampak belakang ditempatkan jendela pada kamar tidur anak dan kaca mati pada kamar tidur utama.

Rumah sederhana tipe 54 orientasi
tenggara

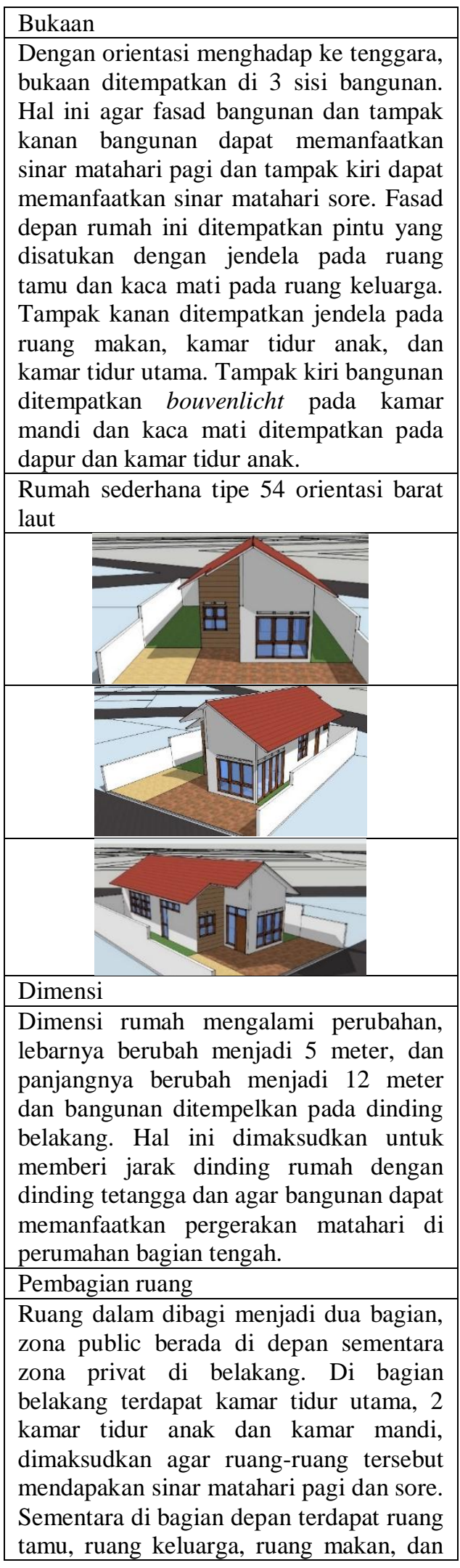


dapur, dimaksudkan untuk dapat memanfaatkan sinar matahari pagi dan sore.

Bukaan

Dengan orientasi menghadap ke barat laut, bukaan ditempatkan di 3 sisi bangunan. Hal ini agar fasad bangunan dan tampak kanan bangunan dapat memanfaatkan sinar matahari sore dan tampak kiri dapat memanfaatkan sinar matahari pagi. Fasad depan rumah ini ditempatkan jendela pada ruang tamu dan dapur. Tampak kanan ditempatkan jendela pada kamar tidur anak bouvenlicht pada kamar mandi dan kaca mati pada ruang tamu dan ruang keluarga. Tampak kiri bangunan ditempatkan jendela pada kamar tidur utama, kamar tidur anak, dan dapur, pintu yang disatukan jendela pada ruang tamu.

Rumah sederhana tipe 54 orientasi barat daya

Dimensi
Dimensi rumah mengalami perubahan,
lebarnya berubah menjadi 7 meter, dan
panjangnya berubah menjadi 8 meter dan
bangunan ditempelkan pada sisi kiri. Hal
ini dimaksudkan agar bangunan dapat
memanfaatkan pergerakan matahari di
perumahan bagian timur.
Pembagian ruang
Ruang dalam dibagi menjadi dua bagian,
zona public berada di depan sementara
zona privat di belakang. Di bagian
belakang terdapat kamar tidur utama dan
2 kamar tidur anak, dimaksudkan agar
ruang-ruang tersebut mendapakan sinar
matahari pagi. Sementara di bagian depan
terdapat ruang tamu, ruang keluarga,
ruang makan, dapur, dan kamar mandi,
dimaksudkan untuk dapat memanfaatkan
sinar matahari pagi dan sore.
Bukaan

Dengan orientasi menghadap ke barat daya, bukaan ditempatkan di 3 sisi bangunan. Hal ini agar fasad bangunan dan tampak kanan bangunan dapat memanfaatkan sinar matahari sore dan tampak belakang dapat memanfaatkan sinar matahari pagi. Fasad depan rumah ini ditempatkan pintu yang bersatu dengan jendela pada ruang tamu, kaca mati pada dapur, dan bouvenlicht kamar mandi. Tampak kanan ditempatkan kaca mati pada ruang keluarga. Tampak belakang bangunan ditempatkan jendela pada kamar tidur utama dan kamar tidur anak.

Rumah sederhana tipe 54 orientasi timur laut

Dimensi

Dimensi rumah mengalami perubahan, lebarnya berubah menjadi 7 meter, dan panjangnya berubah menjadi 8 meter dan bangunan ditempelkan pada sisi kanan. Hal ini dimaksudkan agar bangunan dapat memanfaatkan pergerakan matahari di perumahan bagian timur.

Pembagian ruang

Ruang dalam dibagi menjadi dua bagian, zona public berada di depan sementara zona privat di belakang. Di bagian belakang terdapat kamar tidur utama dan 2 kamar tidur anak, dimaksudkan agar ruang-ruang tersebut mendapakan sinar matahari sore. Sementara di bagian depan terdapat ruang tamu, ruang keluarga, ruang makan, dapur, dan kamar mandi, dimaksudkan untuk dapat memanfaatkan sinar matahari pagi dan sore.

\section{Bukaan}

Dengan orientasi menghadap ke timur laut, bukaan ditempatkan di 3 sisi bangunan. Hal ini agar fasad bangunan dan tampak kiri bangunan dapat memanfaatkan sinar matahari pagi dan tampak belakang dapat memanfaatkan sinar matahari sore. Fasad depan rumah ini ditempatkan pintu yang bersatu dengan jendela pada ruang tamu, kaca mati pada dapur, dan bouvenlicht kamar mandi. Tampak kiri ditempatkan kaca mati pada ruang keluarga. Tampak belakang bangunan ditempatkan jendela pada kamar tidur utama dan kamar tidur anak. 


\section{Kesimpulan}

Perencanaan rumah tinggal sederhana tipe 54 yang diteliti mengatasi masalah tata ruang dalam dan pencahayaan. Untuk mengatasi masalah tersebut direncanakanlah organisasi ruang yang berbeda berdasarkan orientasi bangunan. Rumah dibagi dua zona, depan belakang atau kiri kanan agar aktivitas tetap nyaman dan tidak ada ruangan yang dikelilingi ruangan lainnya. Selain itu untuk mengatasi masalah pencahayaan direncanakan bukaan-bukaan pada bidang-bidang yang terkena sinar matahari. Oleh karena itu akan lebih baik jika rumah sederhana tipe 54 ditata ruang dalamnya berdasarkan orientasi bangunannya, dibagi dua zona, dan menempatkan bukaan pada bidangbidang yang terkena sinar matahari.

\section{Daftar Pustaka}

Habraken, N. J. (1976), Variation: The Systematic Design of Supports. Massachusetts: Laboratory of Architecture and Planning MIT.

Karyono, Tri Harso. (2016), Arsitektur Tropis. Bentuk, Teknologi, Kenyamanan dan Penggunaan Energi. Indonesia: Erlangga

Mangunwijaya, Y. B. (1980), PasalPasal Penghantar Fisika Bangunan. Jakarta: PT Gramedia Jakarta.

Suryowiyono, T. T. W. (1982), Dasar Perencanaan Rumah Tinggal, Jakarta: Pustaka Sinar Harapan.

Yudohusodo, Siswono, dkk, (1994), Rumah Untuk Seluruh Rakyat. Jakarta:
INKOPPOL. 
Jurnal Teknik Arsitektur ARTEKS, Volume. 2, Nomor 2, Juni 2018 ISSN 2541-0598 